E-Journal of Tourism Vol.8. No.2. (2021): 197-206

\title{
Bali Imagined in the Context of Tourism
}

\author{
I Nyoman Darma Putra ${ }^{1 *}$, Michael Hitchcock ${ }^{2}$ \\ ${ }^{1}$ Centre of Excellence in Tourism Udayana University, Indonesia \\ ${ }^{2}$ Goldsmiths, University of London, United Kingdom \\ *Corresponding Author: idarmaputra@yahoo.com \\ DOI: https://doi.org/10.24922/eot.v8i2.71449
}

\begin{abstract}
Article Info
Submitted:

June $2^{\text {nd }} 2021$.

Accepted:

September $17^{\text {th }} 2021$.

Published:

September $30^{\text {th }} 2021$
\end{abstract}

\begin{abstract}
The contention that Bali has been imagined in the context of tourism and that these images do not necessarily correspond to the realities of the destination is not entirely new. However, what this paper argues is that imaginings have occurred over time and began well before the advent of tourism, before becoming incorporated into a more fully developed and more globally recognised tourism image with many elements of the 'tourist gaze'. These gazes are not just externally derived, but also owe a lot to local imaginings of what Bali might be, namely the notion that Bali is some kind of heir to the renowned Hindu-Javanese kingdom of Majapahit based in Java. This paper traces the evolution of these images blending earlier reports of seafarers, colonial administrators both Dutch and British, as well as artists who have lived on the island, into the world of the contemporary media-scape.
\end{abstract}

Keywords: imagined communities, the tourist gaze, colonialism, media-scape

\section{INTRODUCTION}

Imagined Communities: Reflections on the Spread of Nationalism (1991) is the title of Ben Anderson's widely disseminated and hugely cited monograph, which many believe was inspired by his experience of Indonesia. Anderson would have been familiar with the nation building projects of a republic proclaimed by Sukarno in 1945 be it the famous national monument (Monas) in Freedom Square that tells the story of Indonesia's evolution over time in dioramas or the heroic statues that line Jakarta's most popular thoroughfares. He would also have been familiar with the open air museum known as Taman Mini built by Sukarno's successor, Suharto, with its message to this vast sprawling nation of many cultures and languages with the message 'That You Should Know One Another'. If you read the brochure written to accompany the opening of this museum-cum-theme park, there is no doubt that it is a nationalist statement and a somewhat spectacular form of political imagining.

Imagined Communities' is often seen as a work of politics, but there are other ways of looking at the work not least because of the author's emphasis on the 'style' in which such entities are imagined. What we aim to achieve here is an examination of the cultural ways in which such imaginings happen and we combine our approach with insights from another great figure social science, John Urry and his seminal work the 'Tourist Gaze' (1990). The focus of this book is the Indonesian island 
of Bali, which has been imagined in many ways, both by the Balinese themselves and many other external interlocutors ranging from early traders and Dutch colonialists to writers, artists, photographers film-makers to mention but a few, as well as tourism, the backbone of the island's economy. Both authors are well aware that our approach is not entirely novel as others have paved the way in works such as Boon's The Anthropological Romance of Bali (1977), Picard's Bali: Cultural Tourism and Touristic Culture (1996) and Vickers's Bali: A Paradise Created (1989).

\section{LITERATURE REVIEW}

\section{The Imagining of The 'Wong Majapa- hit'}

As this is not a history, though there are historical elements, the authors have decided to begin this account of how Bali has been imagined over time with the widespread belief in Bali, which has been echoed over the centuries by Western writers that the island is the living and breathing heir of a kingdom based in neighbouring Java that once held sway over much of the archipelago, Majapahit (1293 to circa 1517). Interestingly, this kingdom is itself very much a form of imagining as it arose out of an encounter with another formidable Asian entity, the Yuan Dynasty of China that had tried to invade Java without success in the final outcome. The name of this kingdom seems to inculcate the suffering of the people at the time as its name includes the word 'bitter' (pahit). Whether or not this kingdom sat the centre of an empire wielding immense power over the archipelago known today as Indonesia is outside the remit of this volume, though the discovery of a $14^{\text {th }}$ century manuscript in Lombok known as the Negara Kertagama reveals linkages between Majapahit and large numbers of other polities across this vast swathe of islands. Once it was translated the manusc-

ript helped fuel the sense of contemporary Indonesian nationalism and the story sits centre stage in accounts of country's rise to self-determination.

To outsiders this may seem a little odd as Indonesia is today the world's largest Muslim nation whereas Majapahit - its spiritual forebear - was a major Hindu state leaving Bali and neighbouring areas in Java and Lombok as a kind of minor bastion of a religion that once held sway over what we know today as Indonesia. A minor digression on Java is needed here to explain this state of affairs before returning to Bali, the central topic of this book. The simple point is that the Javanese, especially in the centre and east of the island, never did lose a sense of their Hindu heritage despite their conversion to Islam, and many continue to refer to their faith as Islam Jawa and to themselves as Kejawen (in the Javanese tradition). It is no mistake that the name of the luxury hotel built by the Sarkies brothers in Surabaya, which was the scene of intense nationalist activity, was changed from the Orange Hotel (Hotel Oranje) to the Hotel Majapahit, which is how it is known today.

Historians seem to largely agree that this great Hindu kingdom became surrounded by dynamic Islamic polities, possibly enriched through their connection with Islamic global trade routes that pre-dated the Western ones, and eventually collapsed. We cannot be sure how this happened and it is beyond the purview on this work to go into this in detail because what is important to how Bali has been imagined over time with the claim that the Balinese elites are Wong Majapahit (people of Majapahit) who have retained the culture or heritage of this ancient kingdom. What is meant by 'elites' here are the so-called titled castes, Triwangsa (three nations), of Bali's Hindu society, though the term 'caste' is used hesitantly here as it is a Portuguese derived term that was coined to express the complexities of Indian religion and society and 
has never been truly appropriate. It might be better to consider this elite has having a system of titles whereas the majority of Balinese are consider to be outsiders or Jaba. There is a debate in the literature as to whether these titled people may be considered to be an old Austronesian elite who may be loosely described as 'heavenly born' and who have acquired some of the trappings of Hindu notions of superiority dating from the Majapahit era and earlier. The central point here is that they think of themselves as Wong Majapahit, which is one of the central prisms of how they view their Bali.

The story of the Majapahit migration to Bali has several versions and is assumed by many academics to be shrouded in mystery if not partly mythological, but the essential ingredients are as follows. Sensing that their celebrated kingdom and their way of life was under threat, the surviving leaders of Majapahit sought sanctuary in Bali. Sometimes it is said that they were accompanied by musicians, artists and dancers, who created the rich artistic heritage that flourishes in Bali today. Certainly, Bali shares with Java many cultural features such as the renowned shadow theatre, though the Balinese version appears to be more naturalistic whereas the Javanese version is highly stylised. Perhaps this is because of the adoption of Islamic prohibitions on idolatry, though there could be other reasons as these restrictions were never universally enforced in the Islamic world. The Balinese also share a love of pattern-welded and highly decorated kris and share a common folklore and aesthetic with their neighbours to the west. Both cultures have a tradition of gong orchestras known as gamelan, though once again there are significant differences. Could these artistic genres simply have spread from Java to Bali through cultural contact, and does the cultural flow have to be one way only. The answer is that it will probably never know for sure as the

http://ojs.unud.ac.id/index.php/eot documentary details are lacking.

One striking omission in Bali's rich cultural register is the lack of a batik making tradition. Given the centrality and sophistication of this resist dye technique in Java's court culture and this is perhaps surprising when you consider how portable are the tools used to make batik, known as canting tulis. Moreover, batik is not unknown in Bali s it appears in various cultural forms such as in the costume of the Barong Macan, though it was not made locally and originates in Lasem in north Java. There is also a more recent fashion for preparing batik in Bali, which is an introduced activity aimed at tourists. It is also interesting to reflect that Bali itself possesses some sophisticated textile techniques that appear not to be known in Java, such as the renowned double ikat method of Tenganan. What is perhaps worth bearing in mind is that cultural transmissions or exchanges do not invariably involve the complete package and can be haphazard and heavily dependent on the personal interests and tastes of those involved at the time. It also might be useful to refer to the concept of peer polity interaction (Renfrew and Cherry, 1986), though the edited volume does not specifically feature Indonesia in its wide coverage of archaeological debates.

Given that this is a discussion on how Bali is and has been imagined in the style of Ben Anderson is it sufficient simply to acknowledge the inconsistencies in the historical record and to simply acknowledge that the elites of Bali seem pretty certain that they are the heirs to Majapahit even though there are some local academics who are not entirely convinced. The point is that certain influential groups imagine Bali in the style of Majapahit and that is perhaps all that is really important. After all, in the history of England various monarchs have claimed legitimacy through links with King Arthur, a largely mythological figure, and perhaps one of the most notable of these claimants 
was Henry VIII who invoked the lineage of his Welsh ancestors to bolster a claim to the throne that was not always secure. This is an interesting parallel as it is Bali's association with Majapahit which makes possible to embed this predominantly Hin$\mathrm{du}$ Island into the larger political of predominantly Muslim Indonesia. There is also another reason that is worth mentioning at this juncture, though we will return to it later, which was that Indonesia's founding president, Sukarno, had a Balinese mother. $\mathrm{He}$ and his followers were firmly attached to the idea of a religiously plural republic, which is embodied in the state code of five principles known as Pancasila.

There is of course another take on the source of Bali's rich and diverse cultural heritage, not least with regard to the performing arts. A very interesting review of how we might regard cultural traditions is provided the opening section of Matthew Cohen's (2016) Inventing the Performing Arts: Modernity and Tradition in Colonial Indonesia. Cohen starts with a reference Edward Shils' (1981) telling remark that tradition is a consensus between living generations and generations of the dead, bur goes on to point out that this little consensus in this as it appears to be a 'constant battlefield'. He points out that many of these battlers regard tradition strategically as a collet ion of resources and reservoir of ideas that enable local arts practitioners to resist the global forces of cultural homogenization. This is not so far from Anderson's perspective in that it recognises the dynamic nature of cultural forms as opposed to concerns about authenticity. Cohen also examines Mark Hobart's (2007) line of argument that dance in Bali did not exist in its aestheticized form until the arrival of Western administrators, scholars and tourists, which comes quite close to Hobsbawm's (1983) notion of 'invented tradition'. It was the interest shown in these forms of dance by these important foreign- ers combined with economic possibilities that lead to the relatively recent evolution of Bali's complex and aesthetically pleasing expressions of dance.

Certainly, there is an element of this, but we should remember that Bali has a long court tradition and whether or not we take the stories of the Wong Majapahit for granted, it would appear to be reasonable to argue that notions of aesthetics are not entirely new and it occur in other Indonesian court-based societies that were not so well favoured with the attention of administrators, scholars and tourists as Bali was. Both the authors of this book have documented expressions of aesthetics in both Hindu and Muslim societies, and one should not forget the writings of the late Andrew Duff-Cooper on the aesthetic values of Lombok's Hindu peoples. Hitchcock's overview (1991) of textiles across the archipelago, though long outdated, revealed a diversity of aesthetic traditions, though it also indicated clearly when there were Chinese, Indian and western borrowings. What we are talking about is a synthesis in which imported and local elements are re-imagined and re-created amid the generations.

\section{The Western Imagining of Bali}

Bali excited Western imagination after illustrations and texts the West's earliest encounters in the 16th Century. That it was a domain recognising kings seemed familiar; that it had strange and frightening customs was not. Bali's image received another twist from Raffles' History of Java (1817), which projected the Balinese as heirs of a Hindu heritage that once flourished in Java. The Dutch invasion (1906-1908) and the colonization of Southern Bali unleashed a brutality that the occupier tried to mitigate through economic reconstruction, ushering in tourism, as Bali was not suitable for mines or plantations. Krausess Bali (1912) created a slightly lurid but tourist-friendly image of the island $\gg \mathrm{s}$ culture. 
The colonial authorities later adopted the image of the dancer as emblematic of Bali, and, as tourism developed in the New Order era, they further burnished Bali's image as a beautiful, exotic and culturally rich island. Film and photography also played key roles in creating Bali's image from the time of the artist Walter Spies (1920-30s) until the 21 st century. 2010 saw the production of Eat Pray Love starring Julia Roberts as the newly divorced Elizabeth Gilbert who embarks on a quest for self-discovery, finding food in Italy, prayer in India, and finally love in Bali. This dramatization of the island of love, while at odds with reality, is only the most recent insertion of Bali into its ever more globalized mediascape, and the reinforcement of longstanding and often conflicting images for a pervasive tourist gaze and its far-reaching influences.

Cornelis de Houtman's visit to Bali, although possibly not the first Western ship to reach the island, in 1597 left a longlasting impression in The Netherlands and further afield. The English version of Houtman's report is based on unpublished literature left by Richard Hakluyt, which was edited by Purchas in 1624. Purchas embellished the original work to highlight trade opportunities when describing the socalled King of Bali and his entourage, the Hindu religion of the island and the practice of suttee.

For Europeans Bali was an extension of India which dwelt on one hand on its exotic features while on the other it was seen as familiar and king-honouring. These images were built on over the centuries of contact with reports of slave dealing and ferocity, but the original fascination with practices such as suttee endured. But as the $18^{\text {th }}$ century progressed Dutch views became less charitable and even as a nuisance for interfering in affairs in Dutch controlled Java, but interestingly value the martial skills of the Balinese, particularly as mountain soldiers. During the period of British rule in Java, Raffles famously admired the pre-Islamic civilization of Java, which he associated with the Bali of the period and considered to be a 'commentary on the ancient condition of the natives of Java' (Raffles, 1817, 2). Ultimately, trade concerns were always at the fore as the Dutch vexed about Bali's freedom the trade with nearby British-held territories in Asia.

However, it took a long time for the Dutch to completely control the island and when they did so (1906-08) it ended in bloodshed as two Balinese kingdoms fought in suicidal endings known as the Puputan, which was essential for the rulers and aristocrats to die gloriously. As news of the massacres got out, Holland's desired image as an 'ethical' colonial ruler was severely tarnished. The Dutch were in a quandary as Bali was hilly and mountainous and it was not easy to develop plantations; it also had few natural resources that could be mined or quarried.

As has been famously argued by a number of Western scholars, notably Michael Picard, the Dutch opted to introduce tourism, not only to help rejuvenate the economy, but also to provide holiday opportunities close to hand for its administrators and traders. Balinese culture was to be a key plank of this strategy and in order to conserve this precious heritage they introduced a policy, which seems strange in the $21^{\text {st }}$ century, which was known in Dutch as 'Balisering' or Balinization (Picard, 1993). The Balinese were to be taught by their colonial overlords on how to be more authentically Balinese in the name of tourism, and to these ends a variety of media were employed to get across the message. Some of the most remarkable and widely popular texts and images were drawn from a book published in German in 1918 by Gregor Krause.

The date is interesting as it was the aftermath of the First World War and the book's appeal lay partly in its depiction of 
an unsullied paradise. Krause appears to have been impressed by the dignity of the people and the consideration they showed foreigners, and like earlier commentators he dwelt on the subject of kingship. But his favourite theme was what he took to be the organic link between art, society and religion. He regarded the peasantry as being the 'true' Balinese living in harmony with nature. But some of his more serious intentions, his romanticism and his support of colonialism, were soon overshadowed by the promotional activities of the nascent tourism industry. Bali's 'tourist gaze' in all its familiarity had emerged.

\section{RESULTS AND DISCUSSION}

\section{Bali and The Early Tourist Gaze}

It is widely agreed in the critical literature on tourism that the promotion, presentation and experiences associated with this leisure activity often create an unreal space in which local identities, notably those of the visited and possibly even those of the visitors themselves, are modified, contrived or even staged so that they conform to the visitor's expectations. Lanfant famously argued that the reconstruction of identity often begins with the "gaze of the foreigner' acting as a kind of reference point and guarantor of identity" (1995, p. 36). John Urry (1992) gave us the analytically useful expression The Tourist Gaze, a perspective that throws light on the link between tourism and self-actualisation, and explores the connection between mobility in modern and postmodern experience with tourism as a choice of lifestyle and/or consumption (not always difficult to differentiate). In such preconditions, the gaze is a concept embodying ways of looking at the world which simultaneously modifies or even creates from scratch what is seen and the way of seeing.

The 'gaze' appears to be quite powerful in the context of popular culture where a lot of tourism relies on a whole panoply of promotional measures and in situ experiences to interpret whole ways of life and cultural systems. We might then ask who is doing what to whom and in the case of colonial Bali the answer is not only obvious but has been well covered in the literature on the humanities and social scientists. The Dutch, for reasons explained above, had an industry to get off the ground and consequently used all the marketing and media tools, as well as expertise, at their disposal to get the show moving.

A trip to many a Dutch library or archive quickly reveals the volume of this material that is kept on record and it is not the purpose to go into detail here as much of it is and remains familiar: dancing girls, exotic festivals, romantic landscapes and wave-kissed beaches to name but a few. If this is all a bit obvious then why continue with this discussion? And it is here that the authors of this paper would like to offer a slightly different route around the tourism gaze impasse, namely the arrival in Bali of visual artists, scholars, photographers and film makers who - for want of a better term - gazed on Bali, often actively engaging with locally powerful people, in ways that made them stand out from the usual ballyhoo of the tourism industry even though in many ways they were closely connected with it.

The idea that artists, many of them creative and cultural entrepreneurs, active in the context of a nascent tourism industry is by no means limited to Bali and many examples abound and extend well beyond Asia; what makes Bali significant in this context is the amount information that is readily available on what happened and how these interactions and engagements worked. Bali has also spawned a vast research and popular literature - and it is sometimes said that the cake has been overbaked - but we argue that this misses the point as the abundance of material related 
to Bali provides an opportunity to scrutinise the tourism gaze debate and to offer some different perspectives. Miksic and is fellow editors (2011) rightly call for greater awareness of the 'tourism gaze' in the context of development, but what we argue is that if this laudable aim is to be achieved then the 'gaze' needs to be understood in is variety of manifestations, not least its creative ones, and it is here that we argue that the study of Bali has something to offer.

There were a number of interlocutors in this period heralding from a vast number of different countries - The Netherlands, UK, USA, Belgium, Mexico, Germany, Russia etc. - as well as local actors, notably the royal Cokorda family of Ubud in upland Bali. In a paper like this one it is not possible to explore them all as there are many of them and their life stories are wellknown, often quite different and difficult to capture in a limited number of words. Thus we have accordingly selected just a few of them for discussion here in order to illustrate our argument about the need to nuance the 'tourist gaze'. Our point is that there were many interactions between these people over time which were frequently creative, but often quite frivolous and fun, but underlying the often somewhat bohemian appearance lay a seriousness: this is no 'Happy Valley'.

It would take too much time to list all the interlocutors, both foreign and local, involved in this artistic interchange in Bali in the inter-war years, and we propose to focus on just one who not only helped shape Bali's image abroad, but also exerted a long term influence over one of Bali's great cultural tourism centres, Ubud, not least because he collaborated with both the colonial authorities and one of the island's leading families, the Cokordas. His name was Walter Spies and he was a multiple expatriate of Russian and German origin who had commenced his travels in 1923 after working with F.W. Murnau (1889-1923), the great German film director from whom Walter learned much about visual media. Walter famously collaborated with Beryl de Zoete on Dance and Drama in Bali (1938) for which he supplied all but two of the illustrations (Hitchcock and Norris, 1995).

Walter's photographs were carefully planned and executed and they provide a highly aestheticized record of Bali's performing arts, and though readership of the book may have been limited, it was not the only outlet for this artist's vision of Bali. He was, for example, employed by the colonial authorities to contribute to the Exposition Coloniale in Paris in 1931 and with fellow artist Rudolf Bonnet he was closely involved in the growth of the Ubud-based artists' association known as Pita Maha. Works produced by these artists were often destined for tourists, but finer pieces of work also ended up in the Bali Museum with which Spies was closely associated. Without the support of the Cokorda family none of this could have happened as it was they who provided Walter with the land to develop his studio-cum-hotel at nearby Campuan. Walter himself was also a painter and his dreamlike pictures based on $\mathrm{Ba}-$ linese legends were to find their way into the hands of upscale tourists and travellers. $\mathrm{He}$ also collaborated with von Plessen and Dahlseim on the film The Island of Demons (1931) and was such was Spies' reputation globally that film stars such as Charlie Chaplin made their way to what was becoming a major cultural centre, Ubud.

Tourism declined during the war years when Bali like the rest of what is now Indonesia was occupied by the Japanese, though the invaders themselves had their own long term plans about how places such as Indonesia would form a 'Beautiful South' for future tourists. But this was not to happen as Indonesian passed back briefly into Dutch hands and then emerged as a nation in its own right under Sukarno's leadership (1945-1966). There were attempts to revive 
the tourism industry of the inter-war years, not least with the construction of the Bali Beach Hotel in 1963-1966 with the help of Japanese funding, but it was not until the accession of Suharto (1966-1998) that the industry started to gather pace.

\section{The Cumulative Tourist Gaze}

By the time of the boom in tourism arrivals that followed the rule of Suharto's New Order government, Bali's tourist gaze had acquired a very wide range of accretions, including the persistence of earlier manifestations such as 'exotic', 'artistic' and 'erotic'. Perhaps under the heading of the first of these we might include the popularity of local cremations both local and royal. One of first big cremations to attract widespread attention was that of Tjokorda Gde Agung Sukawati in January 1979 and the fact that it was combined with Bonnet's ashes ensured that it was not only recorded in the Bali Post, but was widely circulated in The Netherlands, the home country of the artist. Perhaps the most globally famous of these royal cremations was that of Tjok Gde Agung, Cokorda's third wife, in 2004, which reported on a host of international news channels such as ABC Australia, BBC, and CNN.

The tourist gaze also seems to have been incorporated into local art forms as these became more accessible over time to foreigners. For example, the ngerupuk of torch fire parade prior Nyepi was not open to foreigners as was the case with Margaret Mead in the 1930s as her car was stopped by village security as white people were not deemed to be appropriate participants.

Arguably, the most widely cited accounts of how Bali came to be seen as a romantic holiday island is Adrian Vickers' Bali: A Paradise Created (1989). Vickers devotes quite a bit of space to film, notably The Road to Bali (1952) starring Bob Hope, Bing Crosby and Dorothy Lamour. Although the film had little to do with the realities of Bali, the tropes it relied on endure until this day. In fact the seeds sown in 1952 appear to have lived on until 2010 with Eat Pray Love starring Julia Roberts. She plays newly divorced Elizabeth Gilbert who embarks on a quest for self-discovery, finding food in Italy, prayer in India, and finally love in Bali.

\section{Bali's Globalized Media-Scape}

The dramatization of Bali as the island of love is at odds with reality, but it is the one that has outlived the other versions of the foreign gaze and possibly is the one most in keeping with the demands of modern tourism. It can also be given a pedigree that fits well with the $16^{\text {th }}$ century story of the Dutch sailors who jumped shop, allegedly on account of the charms of Balinese women. The other slightly more discordant images such as 'strange', 'violent' and even 'exotic' Bali do not make good copy for advertising tourism. However, there is another image that has stood the test of time is that of 'heritage' Bali in the sense of the Balinese being custodians of something that existed in the past, the version expressed by Raffles as early as 1817, which finds expression in the various definitions of World Heritage, notably the Balinese Subak irrigation system or rice cultivation culture.

There does not yet appear to be a published analysis of the shock that at least some visitors feel when they realise that Bali does not quite live up to its 'love island' image and the island has not yet been assigned a syndrome like that of Paris in which some Japanese tourists experience a severe kind of shock when they discover that the city differs from their expectation. Known as the Syndrome de Paris (パリ症 候群 in Japanese), it was identified by Professor Hiroaki Ota in 1986 (1991) and is described as a psychopathology relating to travel. However, there are many accounts of this kind of 'shock' in the media and 
particularly on social media in association with Bali. We are not suggesting that there is something that can clearly be identified as the Bali Syndrome, but what we are documenting is that the current images of Bali have historical pedigrees even if they are out of kilter with the realities of this island destination. It is also important to appreciate the contribution of Yamashita's Bali and Beyond: Explorations in the Anthropology of Tourism (2003) on what role Bali has played in promoting the tourism outlook of other islands in Indonesia.

It is beyond the scope of this paper to quantify how Bali has shot to international attention in the media in the time of Covid-19, but it is interesting to reflect on the sheer scale of the coverage of the island's plight for what is a relatively small island destination in international terms. Taking just one major global news provider such as the UK's BBC (https://www.bbc.co.uk/ news/world-asia-53900565) it is interesting to see how detailed the coverage on Bali is when one considers that visitors to the island of British origin lie in ninth place as compared with tourists of other nationalities. One could argue that the BBC's audience is global and so that fact that visitors are drawn from a wide variety of feeder countries supports this wide coverage, but the authors of this paper have wondered whether it is as much the way that Bali is imagined that attracts this media coverage as the scale and diversity of its visitor arrivals.

\section{CONCLUSION}

Drawing on a range of perspectives on the construction of images of Bali that have appeared in a variety of disciplines, notably history, anthropology and sociology, this paper has argued that the tourist image or tourist gaze cannot just be understood in the context of tourism. While the authors concur that the touristic images of
Bali do not correspond with many of the realities of Balinese life, they are by no means recent and that these imaginings occurred over time, beginning well before the advent of tourism. They eventually became incorporated into a more fully developed and more globally recognised touristic image (Selwyn, 1996) or what might be called an international 'tourist gaze'. It is assumed in much of the literature that these gazes are externally derived, created by the interface of the tourist industry and visitors to given destinations, but what this paper has argued that the wellsprings of the gaze in the case of Bali are not just an external phenomenon.

Much is also owed a lot to local imaginings of what Bali might be, namely the notion that Bali is some kind of heir to the renowned Hindu-Javanese kingdom of Majapahit based in Java, a kind of museum of a culture that once flourished widely in what is now Indonesia. This paper provides an overview of the evolution of these images over time and how earlier reports of seafarers, colonial administrators both Dutch and British, as well as artists who have lived on the island have contributed to the development of a widely recognised image of Bali that may in some ways be likened to a brand. And it is not a brand that is simply derived from external forces but one that owes much to local imaginings and not least, creativity.

Note: an earlier version of this paper was presented at ICAS 2019 in Leiden, The Netherlands

\section{REFERENCES}

Anderson, B. (1983) Imagined Communities: Reflections on the Origin and Spread of Nationalism. New York: Verso, 1991.

Boon, J. A. (1977) The Anthropological e-ISSN 2407-392X. p-ISSN 2541-0857 
Romance of Bali 1597-1972. Dynamic Perspectives in Marriage, and Caste, Politics and Religion. Cambridge University Press.

Cohen, M. (2016) Inventing the Performing Arts: Modernity and Tradition in Colonial Indonesia. Honolulu: University of Hawai'i Press.

Hiroaki， O. (1991) パリ症候群 [Pari shōkōgun] (in Japanese). Trajal Books.

Hitchcock, M. (1991) Indonesian Textiles. London: British Museum Press.

Hitchcock, M. and Norris, L. (1995) Bali - The Imaginary Museum; The Photographs of Walter Spies and Beryl de Zoete. Kuala Lumpur: Oxford University Press.

Hobart, M. (2007) 'Rethinking balinese dance', Indonesia and the Malay World, 35(101), pp. 107-128.

Hobsbawm, E. (1983) Introduction: Inventing Traditions. In Hobsbawm, E. \& Ranger, T. (eds.) The Invention of Tradition. Cambridge: Cambridge University Press.

Krause, G. (1988) Bali, 1912: Photographs and Reports by Gregor Krause. Wellington, N.Z.: January Books.

Lanfant, M. F. (1995) 'International Tourism, Internationalization and the Challenge to Identity. In Lanfant, M.F., Allcock, J.B. \& Bruner, E.M. (eds.) International Tourism: Identity and Change.', in. London: Sage.

Miksic, J. N., Goh, G. Y. and O'Connor, S. (2011) Rethinking Cultural Resource
Management in Southeast Asia: Preservation, Development, and Neglect. Anthem Press.

Picard, M. (1993) Cultural Tourism in Bali: National Integration and Regional Differentiation. In Hitchcock M., King, V.T. \& Parnwell, M.J.G. (eds.) Tourism in South-East Asia. London: Routledge.

Picard, M. (1996) Bali: Cultural Tourism and Touristic Culture. Singapore: Archipelago Press.

Purchas, S. (1624) Hakluytus Posthumus or, Purchas his Pilgrimes. Cambridge: Cambridge University Press.

Raffles, T. S. (1817) The History of Java. London: Parbury and Allen, and John Murray.

Renfrew, C. and Cherry, J. . (1986) Peer Polity Interaction and Socio-Political Change. Cambridge: Cambridge University Press.

Selwyn, T. (1996) The Tourist Image: Myths and Myth Making in Tourism. New York: Wiley.

Shils, E. (1981) Tradition. Chicago: University of Chicago Press.

Urry, J. (1990) The Tourist Gaze. London: Sage.

Vickers, A. (1989) Bali: A Paradise Created. Singapore and Berkeley: Periplus.

Yamashita, S. (2003) Bali and Beyond: Explorations in the Anthropology of Tourism. Oxford: Berghahn.

de Zoete, B. and Spies, W. (1938) Dance and Drama in Bali. London: Faber and Faber. 